\title{
Polymorphisms in the delta-like 2 homolog gene and their association with growth and meat-quality traits in Qinchuan cattle
}

\author{
N. Yang ${ }^{1}$, L.S. Zan ${ }^{1,2}$, Y.K. Li ${ }^{1}$, J.B. Gao ${ }^{1}$, X.H. Ma ${ }^{1}$, C.Z. Fu ${ }^{1}$, H. Wang ${ }^{1}$ and \\ C. Adoligbe ${ }^{1}$ \\ ${ }^{1}$ College of Animal Science and Technology, Northwest A\&F University, \\ Yangling, Shaanxi, China \\ ${ }^{2}$ National Beef Cattle Improvement of Northwest A\&F University, \\ Yangling, Shaanxi, China \\ Corresponding author: L.S. Zan \\ E-mail: zanlinsen@163.com
}

Genet. Mol. Res. 13 (1): 2130-2139 (2014)

Received March 29, 2013

Accepted September 8, 2013

Published March 24, 2014

DOI http://dx.doi.org/10.4238/2014.March.24.20

\begin{abstract}
The delta-like 2 homolog (DLK2) modulates adipogenesis, hematopoiesis, osteogenesis, and other cell-differentiation processes. In the present study, we detected potential polymorphisms in the DLK2 gene in 604 individuals of Qinchuan cattle by using PCR-RFLP and DNA-sequencing methods. Herein, we identified five novel singlenucleotide polymorphisms (SNPs) (g.888G $>$ A, g.910A $>$ G, g.995G $>$ A, g.4321 A $>$ G, g.4850A $>$ G) and analyzed their association with measured traits. Four of the five analyzed polymorphisms were associated with at least one of the following traits: body weight (BW), chest depth (CD), chest circumference (CC), back fat thickness (BT), and rib-eye area (REA). To the best of our knowledge, our research is the first to report the association of DLK2 gene polymorphisms with growth and meat quality traits in Qinchuan cattle. In summary, the results of our study suggest that the $D L K 2$ gene can be used as a candidate gene in beef cattle breeding.
\end{abstract}

Key words: Polymorphisms; Qinchuan cattle; DLK2 gene; Mutation; Growth and meat traits 


\section{INTRODUCTION}

The delta-like 2 homolog (DLK2) gene encodes the DLK2 protein, also known as epidermal growth factor-like 9 (EGFL9), which is a transmembrane glycoprotein belonging to the epidermal growth factor (EGF)-like-domain family of proteins (Nueda et al., 2007). $D L K 2$ has a widespread pattern of expression, including in the tissues of lung, brain, adipose, testicles, adult liver, placenta, ovaries, and thymus. DLK2 protein participates in the control of adipogenesis, hematopoiesis, osteogenesis, and other cell-differentiation processes that are also modulated by the homologous protein DLK1 (Nueda et al., 2007). Many of the predicted structural and regulatory features of the DLK2 protein are highly homologous to DLK1, including six EGF-like repeats in its extracellular region, a single transmembrane region, and a short intracellular tail (Nueda et al., 2007). By several ways, DLK2 leads to a reciprocal inhibition for NOTCH signaling in preadipocytes and mouse embryonic fibroblasts (SanchezSolana et al., 2011). The NOTCH signaling pathway plays a highly important role in cell differentiation, proliferation, and developmental processes (Demarest et al., 2008), and anomalous NOTCH signaling can lead to tumorigenesis (Wu et al., 2007; Leong and Gao, 2008; Maliekal et al., 2008). It has been proposed that in F2 offspring obtained in breeding, different genotypes of $D L K 1$ gene are associated with fat deposition and lean muscle mass (Kim et al., 2004). DLK1 may reduce intramuscular fat and inhibit adipogenesis, and the muscular hypertrophies of callipyge sheep, while the $D L K 1$ gene is highly expressed in Longissimus dorsi or Supraspinatus as determined by immunohistochemistry (Davis et al., 2004). However, the mechanism by which DLK2 modulates adipogenesis of preadipocyte and C3H10T1/2 cells is opposite to that of the DLK1 protein, and interactions between DLK1 and DLK2 may lead to coordinated control of cellular processes (Nueda et al., 2007). These observations suggest that DLK2 may play a role in determining fat deposits and muscular hypertrophy. So far, research on potential polymorphisms in the bovine $D L K 2$ gene is lacking. Therefore, the objective of this study was to identify DNA sequence variations in the $D L K 2$ gene in Qinchuan cattle breed and determine possible relationships of any polymorphisms identified in $D L K 2$ with growth and meat-quality traits in this cattle species.

\section{MATERIALS AND METHODS}

\section{Animals, genomic DNA, and data collection}

All of the Qinchuan cattle were fed ad libitum concentrate and straw up to the adult stage in Shaanxi province. A total of 604 blood samples collected from veins were obtained from unrelated female Qinchuan cattle grown and stratified by age ranging from 12 to 36 months. Blood samples were treated with $2 \%$ heparin and stored at $-80^{\circ} \mathrm{C}$. Genomic DNA was extracted from blood samples using standard procedures (Sambrook et al., 2002). Five traits were measured, including body weight $(\mathrm{BW})$, chest depth $(\mathrm{CD})$, chest circumference $(\mathrm{CC})$, back fat thickness (BT), and rib-eye area (REA) (Gilbert et al., 1993; Rincon et al., 2009).

\section{Primer design, PCR amplification, and DNA sequencing}

On the basis of the sequence of the bovine DLK2 gene (GenBank accession No. 
AC_000180.1), ten pairs of polymerase chain reaction (PCR) primers were designed by the Primer Premier 5.0 software to amplify the major part of the coding region of the $D L K 2$ gene (Table 1). PCR amplifications were performed in $15-\mu \mathrm{L}$ volumes, containing $50 \mathrm{ng}$ of genomic DNA, $7.5 \mu \mathrm{L} 2 \mathrm{X}$ reaction mix $(200 \mu \mathrm{M}$ of each dNTP, $10 \mathrm{mM}$ Tris- $\mathrm{HCl}$, $50 \mathrm{mM} \mathrm{KCl}$, and $2 \mu \mathrm{L} \mathrm{MgCl}_{2}$ ), $0.2 \mu \mathrm{M}$ of each primer, and $0.5 \mathrm{U}$ Taq DNA polymerase. The PCR amplification protocol was hold at $95^{\circ} \mathrm{C}$ for $5 \mathrm{~min}$, followed by 35 cycles of denaturing at $94^{\circ} \mathrm{C}$ for $30 \mathrm{~s}$, annealing at $\mathrm{X}^{\circ} \mathrm{C}$ (values for " $\mathrm{X}$ " are shown in Table 1) for $30 \mathrm{~s}$, and extension at $72^{\circ} \mathrm{C}$ for $30 \mathrm{~s}$; a final extension was performed at $72^{\circ} \mathrm{C}$ for $10 \mathrm{~min}$. The DNA samples ranged in number from 50 to 100 and were randomly chosen for DNA pooling. After pooled PCR amplification, the PCR products were sequenced directly for identification of SNPs.

\section{Restriction fragment length polymorphism (RFLP)}

PCR products $(10 \mu \mathrm{L})$ were mixed with $2 \mu \mathrm{L} 10 \mathrm{X}$ buffer, $10 \mathrm{U}$ enzyme (Fermentas) and $18 \mu \mathrm{L}$ nuclease-free water, and incubated for $12 \mathrm{~h}$ at the optimal reaction temperature as recommended by the supplier. The digested products were detected by electrophoresis on $2.5 \%$ agarose gels stained with ethidium bromide.

\section{Statistical analysis}

The genotypic frequencies, allelic frequencies, homozygosity $\left(H_{\mathrm{O}}\right)$, heterozygosity $\left(H_{\mathrm{E}}\right)$, polymorphism information content (PIC), effective number of alleles $\left(N_{e}\right)$, and Hardy-Weinberg equilibrium were calculated according to previous methods (Nei and Roychoudhury, 1974; Nei and $\mathrm{Li}, 1979)$. The SHEsis program was used to calculate the LD coefficient ( $\left.\mathrm{D}^{\prime}\right)$ and correlation coefficient $\left(\mathrm{r}^{2}\right)$ between SNPs (http://analysis.bio-X.cn/myAnalysis.php); linkage disequilibrium (LD) was determined by using $\mathrm{D}^{\prime}$ and $\mathrm{r}^{2}$ values. The SPSS software (13.0 Version) was used to analyze the relationship between different genotypes and measured traits in Qinchuan cattle. The following statistical linear model was used:

$$
Y_{i j}=u+G_{i}+A_{i}+E_{i j k}
$$

where $Y_{i j}$ was the trait measured on the individual cattle, $\mu$ was the overall mean for the trait, $G_{i}$ the effect of the ith SNP genotype, $A_{i}$ the fixed effect of age, and $E_{i j k}$ the residual error.

\section{RESULTS}

\section{Analysis of genetic variation of the $D L K 2$ gene}

Ten pairs of PCR primers were designed to amplify exon and partial intron sequences of the $D L K 2$ gene (Table 1). Five SNPs were found after analysis of the $D L K 2$ sequences: one in intron 2 (g.995G $>A$ ), two in exon 2 (g.888G $>$ A and g.910A $>$ G), and two in exon 6 (g.4321 $\mathrm{A}>\mathrm{G}$ and g.4850A $>\mathrm{G}$ ) (Figures 1, 2, 3, 4, and 5). PCR-RFLP methods were adapted to distinguish the genotypes of different individuals. The two mutations 
g.888G $>A$ and g.4850A $>G$ resulted in three genotypes named $G_{1} G_{1}, G_{1} A_{1}$, and $A_{1} A_{1}$ (Figure 1), and $A_{4} A_{4}, A_{4} G_{4}$, and $G_{4} G_{4}$ (Figure 4). The mutations g. $995 \mathrm{G}>\mathrm{A}$ and g.4321 $\mathrm{A}>\mathrm{G}$ resulted in two genotypes named $\mathrm{G}_{2} \mathrm{G}_{2}$ and $\mathrm{G}_{2} \mathrm{~A}_{2}$ (Figure 2), and $\mathrm{A}_{3} \mathrm{~A}_{3}$ and $\mathrm{A}_{3} \mathrm{G}_{3}$ (Figure 3 ). For technical reasons, we were unable to determine genotypes associated with the mutation g. $910 \mathrm{~A}<\mathrm{G}$. The g.888G $>$ A (CCGGG-to-CCAGG) locus, which is located in the 5' UTR of $D L K 2$, is compatible with an $M v a$ I endonuclease restriction site. Therefore, after digestion of primer 1-amplified products by $M v a \mathrm{I}$, three different patterns were obtained as follows: A 327-bp fragment indicated individuals of $G_{1} G_{1}$ genotype, two 284-bp and 43-bp fragments indicated individuals of $\mathrm{A}_{1} \mathrm{~A}_{1}$ genotype, and three 327-bp, 284-bp, and 43-bp fragments indicated individuals of $\mathrm{G}_{1} \mathrm{~A}_{1}$ genotype (Figure 1). After digestion of the PCR product of primer 3 with SmaI, the g.995G>A locus (CCCGGG-to-CCCGAG), which has a $S m a$ I restriction site, could be identified from 2 banding patterns identified as follow: two 156-bp and 74-bp fragments indicated individuals with genotype $\mathrm{G}_{2} \mathrm{G}_{2}$ and three 230-bp, 156-bp, and 74-bp fragments indicated individuals with genotype $\mathrm{G}_{2} \mathrm{~A}_{2}$ (Figure 2). The locus g.4321 A $>$ G (CACATG-to-CACGTG) showed two banding patterns after digestion of primer 7-PCR product by Eco72I. At the g.4321 A $>\mathrm{G}$ locus, one fragment of $310 \mathrm{bp}$ indicated individuals with $\mathrm{A}_{3} \mathrm{~A}_{3}$ genotype and three fragments $(310 \mathrm{bp}$, $235 \mathrm{bp}$, and $75 \mathrm{bp}$ in length) indicated individuals with $\mathrm{A}_{3} \mathrm{G}_{3}$ genotype (Figure 3). The locus g.4850A $>$ G (CACG-to-CGCG) showed three banding patterns after Bsh1236I digestion of a PCR product amplified with primer 10. At the g.4850A $>\mathrm{G}$ locus, one 313-bp fragment indicated individuals of $\mathrm{A}_{4} \mathrm{~A}_{4}$ genotype, two fragments $283 \mathrm{bp}$ and $30 \mathrm{bp}$ long indicated individuals of $\mathrm{G}_{4} \mathrm{G}_{4}$ genotype, and three fragments of $313 \mathrm{bp}, 283 \mathrm{bp}$, and 30 bp indicated individuals of $\mathrm{A}_{4} \mathrm{G}_{4}$ genotype (Figure 4). The mutations g.4321 $\mathrm{A}>\mathrm{G}$ and g. $4850 \mathrm{~A}>\mathrm{G}$ were both located in exon 6 of the $D L K 2$ gene. The mutation g. $4321 \mathrm{~A}>\mathrm{G}$ did not cause an amino acid change in the DLK2 protein; however, the mutation g.4850A $>\mathrm{G}$ caused a change from threonine (ACG) to alanine (GCG) in the translated DLK2 protein (Table 2).

Table 1. Primer sequences for PCR amplification of the $D L K 2$ gene in Qinchuan cattle.

\begin{tabular}{|c|c|c|c|c|}
\hline Primer & Sequence of primer & Sizes (bp) & $\operatorname{Tm}\left({ }^{\circ} \mathrm{C}\right)$ & Region (bp) (Ref.AC_000180.1) \\
\hline \multirow[t]{2}{*}{$\mathrm{P} 1$} & F: 5'-TCCTTCACCTCCTTCCCACG-3' & 327 & 57.6 & $626-952$ \\
\hline & R: 5'-GGACGCACAACAGGCAAACG-3' & & & \\
\hline \multirow[t]{2}{*}{ P2 } & F: 5'-GGCCGGCGCTGACCATGCC-3' & 102 & 60.3 & $890-991$ \\
\hline & R: 5'-GGGAGCGCTCACCTATGGCAG-3' & & & \\
\hline \multirow[t]{2}{*}{ P3 } & F: 5'-GGCCTACATCTCGTTTGC-3' & 230 & 54.8 & $923-1152$ \\
\hline & R: 5'-TGGGGCAAGGTAGAATAG-3' & & & \\
\hline \multirow[t]{2}{*}{ P4 } & F: 5'-GCATCTCAGGCAGCCGAAC-3' & 154 & 58.3 & $1202-1355$ \\
\hline & R: 5'-GCAACCACCGTGCTCCAA-3' & & & \\
\hline \multirow[t]{2}{*}{ P5 } & F: 5'-TTGGAAAGGATAGACAGACT-3' & 429 & 60.3 & $2407-2835$ \\
\hline & R: 5'-GAGGCACTCAATAAATAAGG-3' & & & \\
\hline \multirow[t]{2}{*}{ P6 } & F: 5'-CTCCTGACTCCAAATGCAGT-3' & 382 & 56.9 & $3209-3590$ \\
\hline & R: 5'-GACCCTCAGCCCTAACACTG-3' & & & \\
\hline \multirow[t]{2}{*}{ P7 } & F: 5'-GGGTGGTGGGAGCAGGGAT-3' & 310 & 59.1 & $4087-4396$ \\
\hline & R: 5'-CAGGTTGATGGTGCAGAAGC-3' & & & \\
\hline \multirow[t]{2}{*}{ P8 } & F: 5'-CAACCGCTTCTCCTGCCTCT-3' & 313 & 58.9 & $4336-4648$ \\
\hline & R: 5'-TCGCCGCACCACTTCCTT-3' & & & \\
\hline \multirow[t]{2}{*}{ P9 } & F: 5'-GCTGCTGGGCATCTCCGT-3' & 288 & 57.2 & $4612-4899$ \\
\hline & R: 5'-TGTGGTCTTCCCAGGCTC-3' & & & \\
\hline \multirow[t]{2}{*}{ P10 } & F: 5'-CCAGGAGTGTCAGGTTAGC-3' & 313 & 56.0 & $4822-5134$ \\
\hline & R: 5'-GGACTCCAGGCAGACTTT-3' & & & \\
\hline
\end{tabular}



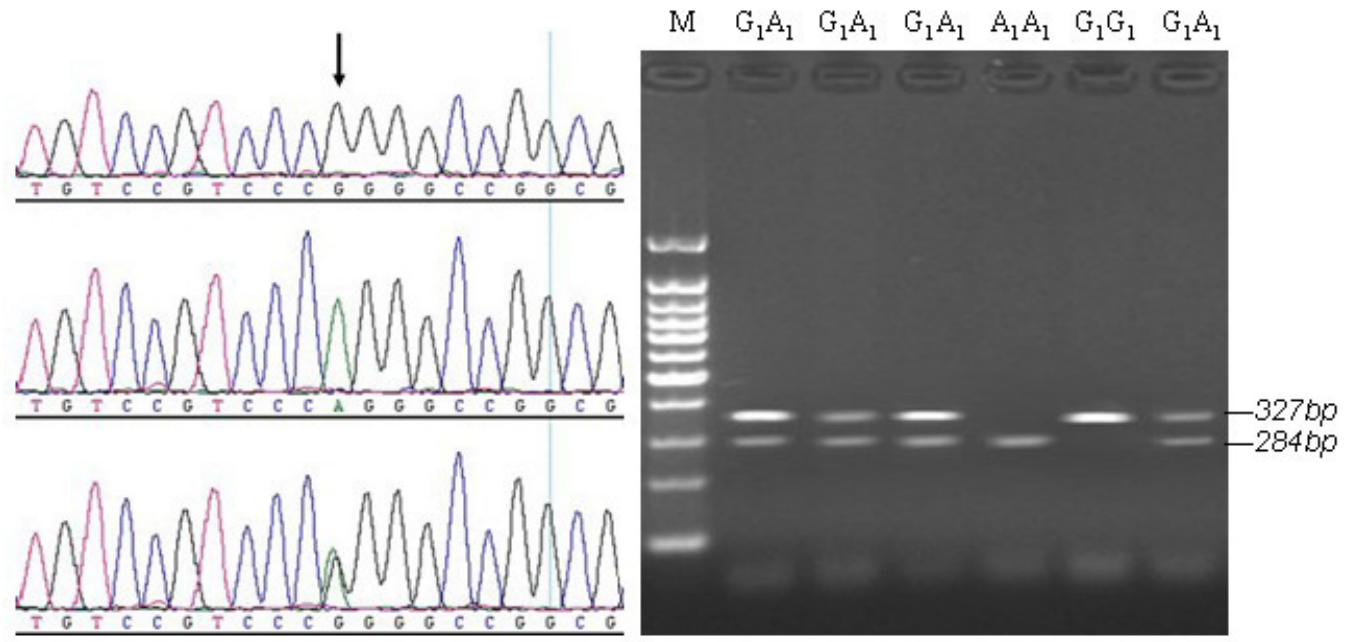

Figure 1. DNA sequencing maps and PCR-RFLP genotypes of the $D L K 2$ gene g.888G $>$ A locus in Qinchuan cattle.

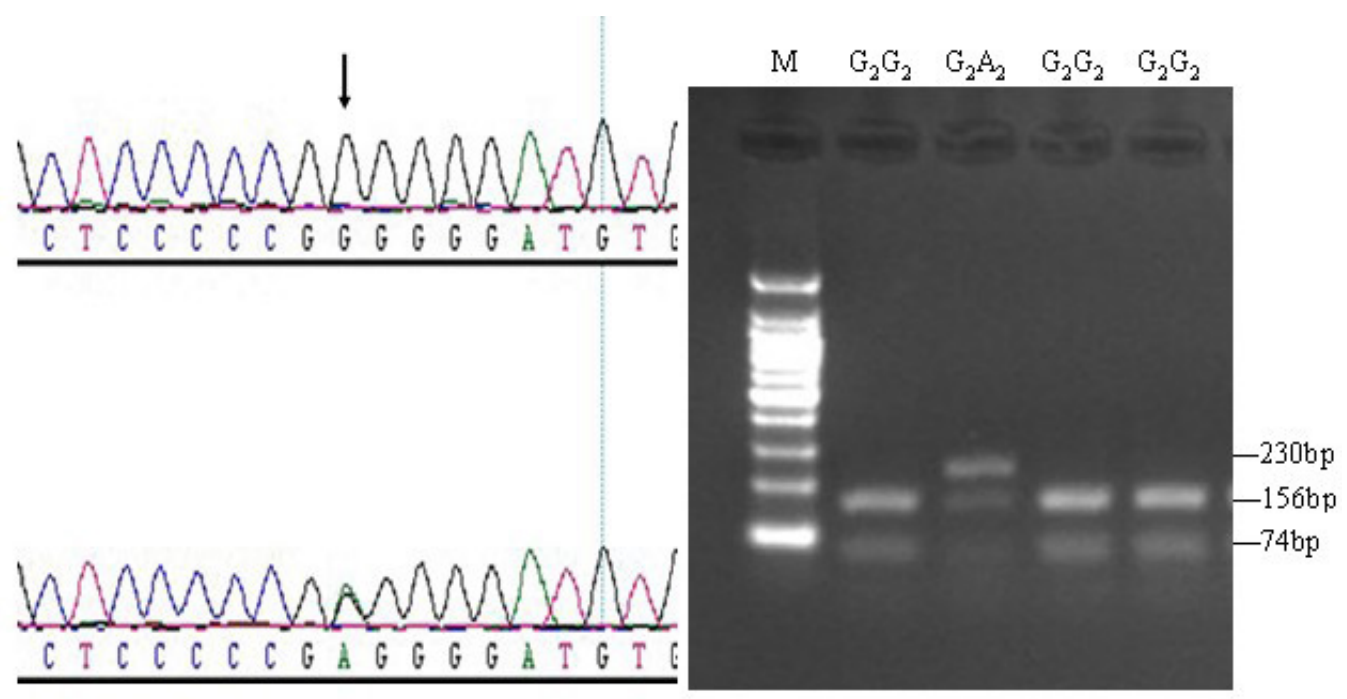

Figure 2. DNA sequencing maps and PCR-RFLP genotypes of the $D L K 2$ gene g.995G $>$ A locus in Qinchuan cattle.

\section{Analysis of population genetic structure}

Table 3 shows the distribution of genotypic and allelic frequencies and of genetic diversity parameters (including $H_{\mathrm{O}}, H_{\mathrm{E}}, N_{\mathrm{E}}$, and PIC) at the four SNPs loci. At the g.995G $>$ A and g.4321 $\mathrm{A}>\mathrm{G}$ loci, mutant alleles were less frequent than the wild-type allele in Qinchuan cattle, while mutant alleles were almost equally represented at the g.888G $>\mathrm{A}$ and g.4850 $\mathrm{A}>\mathrm{G}$ loci. $H_{\mathrm{E}}$, $N_{e}$, and PIC values for the g.995G $>$ A and g. $4321 \mathrm{~A}>\mathrm{G}$ loci were lower than the corresponding 
values for the other two loci. Considering the value of PIC, the g.888G $>\mathrm{A}$ and $\mathrm{g} .4850 \mathrm{~A}>\mathrm{G}$ loci showed a medium polymorphism, whereas the g.995G $>$ A and g.4321 $\mathrm{A}>\mathrm{G}$ loci showed fewer polymorphisms. According to the Table 3, the loci g. $888 \mathrm{G}>$ A, g. $995 \mathrm{G}>\mathrm{A}$, and g. $4321 \mathrm{~A}>\mathrm{G}$ were not in Hardy-Weinberg equilibrium $(\mathrm{P}<0.01)$; in contrast, the g. $4850 \mathrm{~A}>\mathrm{G}$ locus was in Hardy-Weinberg equilibrium $(\mathrm{P}>0.05)$.

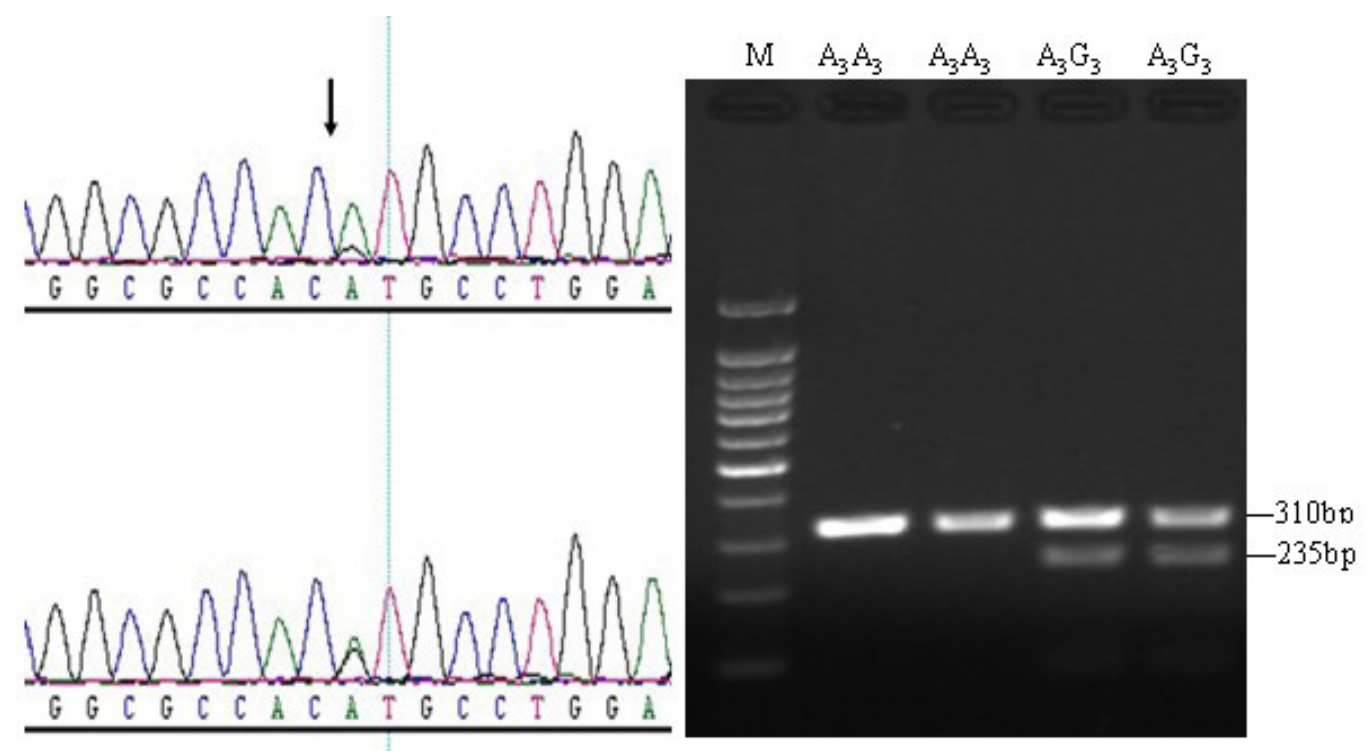

Figure 3. DNA sequencing maps and PCR-RFLP genotypes of the $D L K 2$ gene g. $4321 \mathrm{~A}>\mathrm{G}$ locus in Qinchuan cattle.

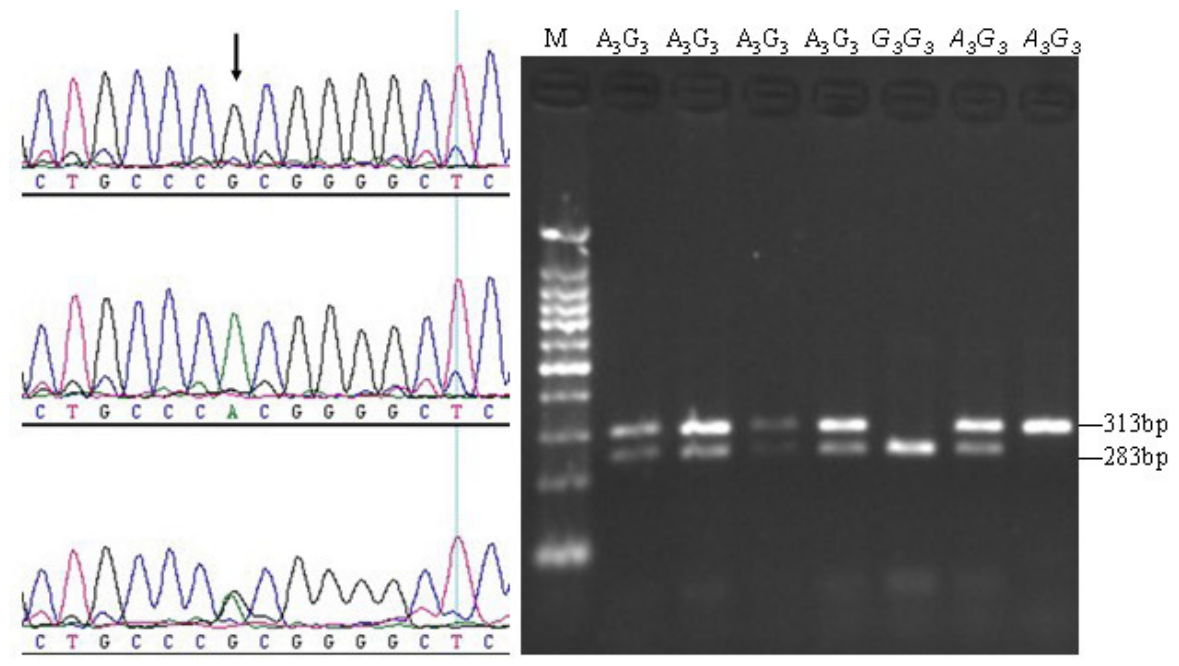

Figure 4. DNA sequencing maps and PCR-RFLP genotypes of the $D L K 2$ gene g.4850A $>$ G locus in Qinchuan cattle. As the 30 -bp fragment was invisible on the $2.5 \%$ agarose gel electrophoresis. 
Table 2. Variations in the $D L K 2$ gene of Qinchuan cattle.

\begin{tabular}{|c|c|c|c|c|}
\hline Locus & Location & SNP & Codon & Amino acid \\
\hline g. $888 \mathrm{G}>A$ & 5'-UTR & $\mathrm{G} / \mathrm{A}$ & & \\
\hline g. $910 \mathrm{~A}>\mathrm{G}$ & Exon2 & $\mathrm{A} / \mathrm{G}$ & AGC-to-GGC & Serine-to-Glycine \\
\hline g. $995 \mathrm{G}>\mathrm{A}$ & Intron2 & $\mathrm{G} / \mathrm{A}$ & & \\
\hline g. $4321 \mathrm{~A}>\mathrm{G}$ & Exon6 & $\mathrm{A} / \mathrm{G}$ & ACA-to-ACG & Threonine-to-Threonine \\
\hline g. $4850 \mathrm{~A}>\mathrm{G}$ & Exon6 & $\mathrm{A} / \mathrm{G}$ & ACG-to-GCG & Threonine-to- Alanine \\
\hline
\end{tabular}

Table 3. Genotype and allelic frequencies and genetic diversity of the $D L K 2$ gene.

\begin{tabular}{|c|c|c|c|c|c|c|c|c|}
\hline Mutation & Genotype & Frequencies & Allelic frequencies & $\chi^{2}$ & $H_{\mathrm{o}}$ & $H_{\mathrm{E}}$ & $N_{\mathrm{E}}$ & PIC \\
\hline \multirow[t]{3}{*}{ g. $888 \mathrm{G}>\mathrm{A}$} & $\overline{\mathrm{G}_{1} \mathrm{G}_{1}}$ & 0.234 & $\mathrm{G}(0.528)$ & $20.129^{* * *}$ & 0.502 & 0.498 & 1.994 & 0.374 \\
\hline & $\mathrm{G}_{1} \mathrm{~A}_{1}$ & 0.589 & $\mathrm{~A}(0.472)$ & & & & & \\
\hline & $\mathrm{A}_{1} \mathrm{~A}_{1}$ & 0.177 & & & & & & \\
\hline \multirow[t]{2}{*}{ g. $995 \mathrm{~A}>\mathrm{G}$} & $\mathrm{G}_{2}^{1} \mathrm{G}_{2}^{1}$ & 0.758 & $\mathrm{G}(0.879)$ & $11.416^{* *}$ & 0.787 & 0.213 & 1.270 & 0.190 \\
\hline & $\mathrm{G}_{2}^{2} \mathrm{~A}_{2}^{2}$ & 0.242 & $\mathrm{~A}(0.121)$ & & & & & \\
\hline \multirow[t]{2}{*}{ g. $4321 \mathrm{~A}>\mathrm{G}$} & $\mathrm{A}_{3}^{2} \mathrm{~A}_{3}^{2}$ & 0.763 & $\mathrm{~A}(0.882)$ & $10.890^{* * *}$ & 0.791 & 0.209 & 1.264 & 0.187 \\
\hline & $\mathrm{A}_{3}^{3} \mathrm{G}_{3}^{3}$ & 0.237 & $\mathrm{G}(0.118)$ & & & & & \\
\hline \multirow[t]{3}{*}{ g. $4850 \mathrm{~A}>\mathrm{G}$} & $\mathrm{A}_{4}^{3} \mathrm{~A}_{4}^{3}$ & 0.295 & $\mathrm{~A}(0.521)$ & 5.391 & 0.501 & 0.499 & 1.997 & 0.375 \\
\hline & $\mathrm{A}_{4}^{4} \mathrm{G}_{4}^{4}$ & 0.452 & $\mathrm{G}(0.479)$ & & & & & \\
\hline & $\mathrm{G}_{4}^{7} \mathrm{G}_{4}^{7}$ & 0.253 & & & & & & \\
\hline
\end{tabular}

$\chi_{0.05}^{2}=5.99, \chi_{0.01}^{2}=9.21$, d.f. $=2 . * *$ Polymorphism was not in Hardy-Weinberg Equilibrium $(\mathrm{P}<0.01)$. No asterisks in the $\chi^{2}$ column means the polymorphism was in Hardy-Weinberg Equilibrium $(\mathrm{P}>0.05)$.

\section{Analysis of LD for the four SNPs}

Haplotypes generally have more informational value than single SNPs. Therefore, we performed LD analysis for the four SNPs in the DLK2 gene in Qinchuan cattle. The LD structure as estimated by $\mathrm{D}^{\prime}$ and $\mathrm{r}^{2}$ was calculated (Table 4 ). The $\mathrm{D}^{\prime}$ value ranged from 0.038 to 0.235 , and the $\mathrm{r}^{2}$ from 0.000 to 0.008 . These results indicated that all mutations were in low LD with each other.

Table 4. Estimated values of LD analysis between 4 mutation sites with in the $D L K 2$ gene.
\begin{tabular}{lllll}
\hline Mutation & g. $888 \mathrm{G}>$ A & g. $995 \mathrm{G}>$ A & g.4321A $>\mathrm{G}$ & g.4850A $>\mathrm{G}$ \\
\hline g. $888 \mathrm{G}>\mathrm{A}$ & & $\mathrm{D}^{\prime}=0.038$ & $\mathrm{D}^{\prime}=0.225$ & $\mathrm{D}^{\prime}=0.065$ \\
g.995G $>$ A & $\mathrm{r}^{2}=0.000$ & $\mathrm{D}^{\prime}=0.071$ & $\mathrm{D}^{\prime}=0.235$ \\
g.4321A $>\mathrm{G}$ & $\mathrm{r}^{2}=0.006$ & $\mathrm{r}^{2}=0.005$ & $\mathrm{D}^{2}=0.005$ & \\
\hline g.4850A $>\mathrm{G}$ & $\mathrm{R}^{2}=0.004$ & $\mathrm{r}^{2}=0.008$ & \\
\hline
\end{tabular}

\section{Analysis of the association of $D K L 2$ SNPs with growth and meat-quality traits}

The association of the four mutations in the $D L K 2$ gene with growth and meat-quality traits (including BW, CD, CC, BT, and REA) in Qinchuan cattle was analyzed (Table 5). At the g. $888 \mathrm{G}>\mathrm{A}$ locus, significant effects on $\mathrm{BW}, \mathrm{CC}, \mathrm{BT}$, and REA were identified. Individuals of $\mathrm{G}_{1} \mathrm{~A}_{1}$ genotype had larger $\mathrm{CC}, \mathrm{BT}$, and REA than individuals with $\mathrm{G}_{1} \mathrm{G}_{1}$ genotype $(\mathrm{P}<0.05)$, heavier $\mathrm{BW}$ than individuals with $\mathrm{A}_{1} \mathrm{~A}_{1}$ genotype $(\mathrm{P}<0.05)$ and $\mathrm{G}_{1} \mathrm{G}_{1}$ genotype $(\mathrm{P}<0.01)$. At the g.995G $>$ A locus, individuals of $\mathrm{G}_{2} \mathrm{G}_{2}$ genotype had larger BT than those with $\mathrm{G}_{2} \mathrm{~A}_{2}$ genotype $(\mathrm{P}<0.05)$. At the g.4321 $\mathrm{A}>\mathrm{G}$ locus, individuals of $\mathrm{A}_{3} \mathrm{~A}_{3}$ genotype had deeper $\mathrm{CD}(\mathrm{P}<$ $0.05)$, larger $\mathrm{CC}(\mathrm{P}<0.05)$ and heavier $\mathrm{BW}(\mathrm{P}<0.01)$ than those with $\mathrm{A}_{3} \mathrm{G}_{3}$ genotype. At the 
g.4850A $>\mathrm{G}$ locus, the individuals of $\mathrm{A}_{4} \mathrm{~A}_{4}$ genotype had larger $\mathrm{BT}(\mathrm{P}<0.01)$ and larger REA $(\mathrm{P}$ $<0.05)$ than those with $A_{4} G_{4}$ genotype and larger $B T$ than those with $G_{4} G_{4}$ genotype $(P<0.05)$.

\begin{tabular}{|c|c|c|c|c|c|c|}
\hline Locus & Genotypes & $\mathrm{BW}(\mathrm{kg})$ & $\mathrm{CD}(\mathrm{cm})$ & $\mathrm{CC}(\mathrm{cm})$ & $\mathrm{BT}(\mathrm{cm})$ & $\operatorname{REA}\left(\mathrm{cm}^{2}\right)$ \\
\hline \multirow[t]{4}{*}{ g. $888 \mathrm{G}>A$} & $\mathrm{G}_{1} \mathrm{G}_{1}$ & $309.72 \pm 8.75^{\mathrm{B}}$ & $57.74 \pm 0.62$ & $158.92 \pm 1.69^{b}$ & $0.83 \pm 0.03^{b}$ & $43.86 \pm 1.32^{\mathrm{b}}$ \\
\hline & $\mathrm{G}_{1} \mathrm{~A}_{1}$ & $334.40 \pm 6.35^{\mathrm{aA}}$ & $58.87 \pm 0.45$ & $162.58 \pm 1.23^{\mathrm{a}}$ & $0.89 \pm 0.02^{\mathrm{a}}$ & $46.69 \pm 0.95^{\mathrm{a}}$ \\
\hline & $\mathrm{A}_{1} \mathrm{~A}_{1}$ & $314.07 \pm 9.90^{\mathrm{b}}$ & $57.83 \pm 0.71$ & $159.83 \pm 1.92$ & $0.83 \pm 0.03$ & $43.86 \pm 1.48$ \\
\hline & $\mathrm{P}$ & 0.005 & 0.061 & 0.031 & 0.039 & 0.047 \\
\hline \multirow[t]{3}{*}{ g. $995 \mathrm{G}>A$} & $\mathrm{G}_{2} \mathrm{G}_{2}$ & $321.59 \pm 5.68$ & $58.34 \pm 0.40$ & $161.09 \pm 1.10$ & $0.88 \pm 0.02^{\mathrm{a}}$ & $46.03 \pm 0.85$ \\
\hline & $\mathrm{G}_{2}^{2} \mathrm{~A}_{2}^{2}$ & $317.20 \pm 8.56$ & $57.95 \pm 0.61$ & $159.79 \pm 1.66$ & $0.81 \pm 0.03^{\mathrm{b}}$ & $44.55 \pm 1.28$ \\
\hline & $\mathrm{P}$ & 0.636 & 0.559 & 0.469 & 0.035 & 0.287 \\
\hline \multirow[t]{3}{*}{ g. $4321 \mathrm{~A}>\mathrm{G}$} & $\mathrm{A}_{3} \mathrm{~A}_{3}$ & $331.44 \pm 5.72^{\mathrm{A}}$ & $58.94 \pm 0.41^{\mathrm{a}}$ & $162.36 \pm 1.11^{\mathrm{a}}$ & $0.88 \pm 0.02$ & $45.56 \pm 0.86$ \\
\hline & $\mathrm{A}_{3} \mathrm{G}_{3}$ & $307.35 \pm 8.57^{\mathrm{B}}$ & $57.35 \pm 0.61^{\mathrm{b}}$ & $158.52 \pm 1.66^{\mathrm{b}}$ & $0.83 \pm 0.03$ & $45.02 \pm 1.29$ \\
\hline & $\mathrm{P}^{3}$ & 0.010 & 0.018 & 0.034 & 0.237 & 0.705 \\
\hline \multirow[t]{4}{*}{ g. $4850 \mathrm{~A}>\mathrm{G}$} & $\mathrm{A}_{4} \mathrm{~A}_{4}$ & $323.56 \pm 8.49$ & $58.37 \pm 0.61$ & $161.79 \pm 1.65$ & $0.90 \pm 0.03^{\mathrm{aA}}$ & $47.28 \pm 1.27^{\mathrm{a}}$ \\
\hline & $\mathrm{A}_{4}^{4} \mathrm{G}_{4}$ & $319.18 \pm 6.94$ & $58.28 \pm 0.49$ & $160.94 \pm 1.34$ & $0.82 \pm 0.02^{\mathrm{B}}$ & $44.20 \pm 1.04^{\mathrm{b}}$ \\
\hline & $\mathrm{G}_{4} \mathrm{G}_{4}$ & $315.45 \pm 8.55$ & $57.77 \pm 0.61$ & $158.60 \pm 1.66$ & $0.83 \pm 0.03^{b}$ & $44.39 \pm 1.28$ \\
\hline & $\mathrm{P}$ & 0.322 & 0.312 & 0.079 & 0.009 & 0.022 \\
\hline
\end{tabular}

Data are reported as least square means \pm standard errors. Values with different superscript lowercase letters of one locus in the same column differ significant at $\mathrm{P}<0.05$. Values with different superscript capital letters of one locus in the same column differ significant at $\mathrm{P}<0.01$.

\section{DISCUSSION}

Previous research on the $D L K 2$ gene has largely focused on its role in modulating cell processes in humans and mice. Nueda et al. (2007) demonstrated that the DLK2 gene affected adipogenesis of 3T3-L1 preadipocytes and mesenchymal C3C10T1/2 cells, and C3H10T1/2 distinguish adipocytes, osteocytes, chondrocytes, and myocytes. Therefore, $D L K 2$ may participate in controlling adipogenesis, hematopoiesis, osteogenesis, and other cell-differentiation processes. To date, no information is available about polymorphisms at the $D L K 2$ gene and the possible association of these polymorphisms with quantitative trait locus (QTL). Rothschild et al. (1997) have urged that it is important to investigate associations of gene polymorphisms with economical traits in farm animals.

In this study, we report the discovery of five novel SNPs in the bovine delta-like 2 homolog gene $D L K 2$, and analyzed the association of four of these SNPs with growth and meat quality traits in Qinchuan cattle. The results showed that the g.995G $>$ A and g.4321G $>$ A loci had only two genotypes and that the frequency of homozygous genotypes was higher than that of heterozygote genotypes. This observation may be the result of an artificial genetic selection. Mutations causing synonymous amino acid exchanges have been reported to affect protein expression by altering or increasing the stability of the mRNA (Capon et al., 2004; Nackley et al., 2006). In addition, "silent" polymorphism changes can affect enzyme substrate specificity (Kimchi-Sarfaty et al., 2007). Additional research has shown that introns can affect transcriptional efficiency of many genes (Greenwood and Kelsoe, 2003; Le Hir et al., 2003). Mutations in the 5' UTR of a gene can affect mRNA stability and modulate the efficiency of translation of mRNA (Woodman et al., 1996; Stefanovic et al., 1999). The mutation g.888 G $>$ A is located in the 5' UTR within a CG-rich region (CCCGGGGCCGGCGC) of the DLK2 gene. This may affect transcription factor-binding sites at a $\mathrm{CpG}$ island. The mutation of g.4850A $>\mathrm{G}$ led to a threonine-to-alanine amino acid change in the translated DKL2 protein, which may affect its 
function. However, we failed to distinguish different banding patterns of the g.910A $>$ G mutation, which, based on the result of DNA fragment sequencing (Figure 5), is predicted to result in the change of a serine to a glycine amino acid. In conclusion, our research showed that differences in genotype of the $D L K 2$ gene had a significant effect on growth and meat-quality traits in Qinchuan cattle. Therefore, the $D L K 2$ gene could be used as a candidate gene for Qinchuan beef cattle breeding in China. However, further research is needed to validate our findings.
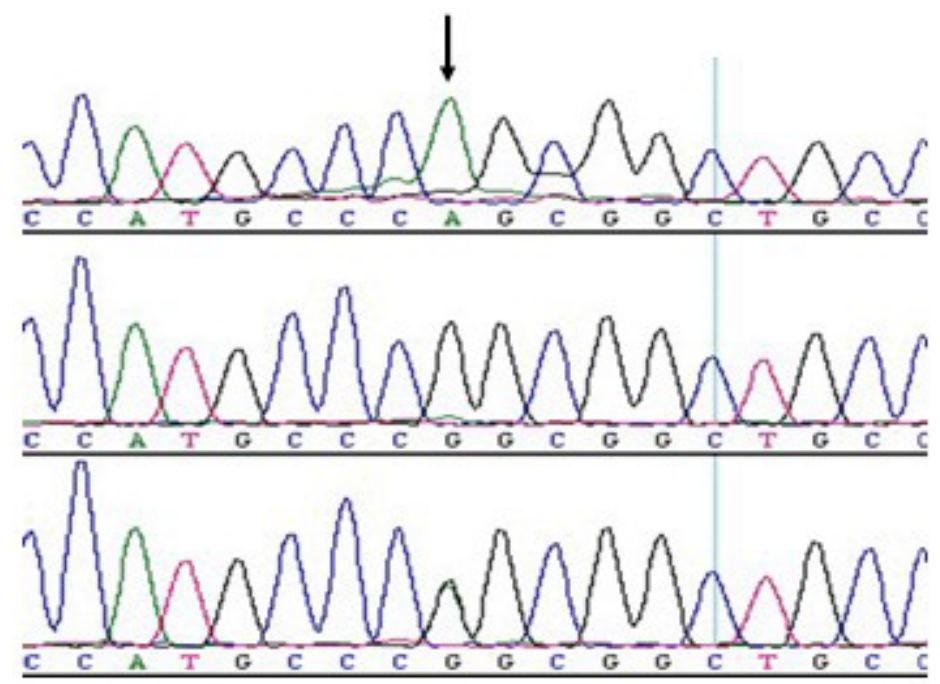

Figure 5. DNA sequencing maps of $D L K 2$ gene g.910A $>\mathrm{G}$ locus in Qinchuan cattle.

\section{ACKNOWLEDGMENTS}

Research supported by the National Twelfth "Five Year" Science and Technology Support Project (\#2011BAD28B04-03), the China National “863" Program (\#2011AA100307), the GMO New Varieties Major Project (\#2011ZX08007-002), the National Beef and Yak Industrial Technology System (\#CARS-38), the Program for Changjiang Scholars and Innovative Research Team (\#IRT0940), and the "13115" Scientific and Technological Innovation Program of Shaanxi Province (\#S2010ZDGC109).

\section{REFERENCES}

Capon F, Allen MH, Ameen M, Burden AD, et al. (2004). A synonymous SNP of the corneodesmosin gene leads to increased mRNA stability and demonstrates association with psoriasis across diverse ethnic groups. Hum. Mol. Genet. 13: 2361-2368.

Davis E, Jensen CH, Schroder HD, Farnir F, et al. (2004). Ectopic expression of DLK1 protein in skeletal muscle of padumnal heterozygotes causes the callipyge phenotype. Curr. Biol. 14: 1858-1862.

Demarest RM, Ratti F and Capobianco AJ (2008). It's T-ALL about Notch. Oncogene 27: 5082-5091.

Gilbert RP, Bailey DR and Shannon NH (1993). Linear body measurements of cattle before and after 20 years of selection for postweaning gain when fed two different diets. J. Anim. Sci. 71: 1712-1720.

Greenwood TA and Kelsoe JR (2003). Promoter and intronic variants affect the transcriptional regulation of the human dopamine transporter gene. Genomics 82: 511-520. 
Kim KS, Kim JJ, Dekkers JC and Rothschild MF (2004). Polar overdominant inheritance of a DLK1 polymorphism is associated with growth and fatness in pigs. Mamm. Genome 15: 552-559.

Kimchi-Sarfaty C, Oh JM, Kim IW, Sauna ZE, et al. (2007). A "silent" polymorphism in the MDR1 gene changes substrate specificity. Science 315: 525-528.

Le Hir H, Nott A and Moore MJ (2003). How introns influence and enhance eukaryotic gene expression. Trends Biochem. Sci 28: 215-220.

Leong KG and Gao WQ (2008). The Notch pathway in prostate development and cancer. Differentiation 76: 699-716.

Maliekal TT, Bajaj J, Giri V, Subramanyam D, et al. (2008). The role of Notch signaling in human cervical cancer: implications for solid tumors. Oncogene 27: 5110-5114.

Nackley AG, Shabalina SA, Tchivileva IE, Satterfield K, et al. (2006). Human catechol-O-methyltransferase haplotypes modulate protein expression by altering mRNA secondary structure. Science 314: 1930-1933.

Nei M and Roychoudhury AK (1974). Sampling variances of heterozygosity and genetic distance. Genetics 76: 379-390.

Nei M and Li WH (1979). Mathematical model for studying genetic variation in terms of restriction endonucleases. Proc. Natl. Acad. Sci. U. S A. 76: 5269-5273.

Nueda ML, Baladron V, Garcia-Ramirez JJ, Sanchez-Solana B, et al. (2007). The novel gene EGFL9/Dlk2, highly homologous to Dlk1, functions as a modulator of adipogenesis. J. Mol. Biol. 367: 1270-1280.

Rincon G, Farber EA, Farber CR, Nkrumah JD, et al. (2009). Polymorphisms in the STAT6 gene and their association with carcass traits in feedlot cattle. Anim. Genet. 40: 878-882.

Rothschild MF and Soller M (1997). Candidate gene analysis to detect genes controlling traits of economic importance in domestic livestock. Probe Newsl. Agric. Genomic. 8: 13-20.

Sambrook J and Russel DW (2002). Molecular Cloning: A Laboratory Manual. 3rd edn. Sci. Press, Beijing.

Sanchez-Solana B, Nueda ML, Ruvira MD, Ruiz-Hidalgo MJ, et al. (2011). The EGF-like proteins DLK1 and DLK2 function as inhibitory non-canonical ligands of NOTCH1 receptor that modulate each other's activities. Biochim. Biophys. Acta. 1813: 1153-1164.

Stefanovic B, Hellerbrand C and Brenner DA (1999). Regulatory role of the conserved stem-loop structure at the 5' end of collagen alpha1(I) mRNA. Mol. Cell Biol. 19: 4334-4342.

Woodman AC, Sugiyama M, Yoshida K, Sugino T, et al. (1996). Analysis of anomalous CD44 gene expression in human breast, bladder, and colon cancer and correlation of observed mRNA and protein isoforms. Am. J. Pathol. 149: 15191530.

Wu F, Stutzman A and Mo YY (2007). Notch signaling and its role in breast cancer. Front. Biosci. 12: 4370-4383. 